\title{
DNA and RNA obtained from Bouin's fixed tissues
}

\author{
S Bonin, F Petrera, J Rosai, G Stanta
}

J Clin Pathol 2005;58:313-316. doi: 10.1136/icp.2004.016477

Background: The use in many countries of acid fixatives, such as Bouin's solution, has limited the use of archival tissue for molecular analysis. An acidic environment is one of the main causes of DNA degradation. Moreover, RNA extraction is difficult in these types of fixed tissues.

Aims: To amplify DNA and RNA from Bouin's fixed tissues. Methods: DNA and RNA were extracted from 20 breast cancer samples that had been routinely fixed in Bouin's fixative. Amplification of several genes using primers that produced amplicons of different lengths was carried out using the polymerase chain reaction (PCR) for DNA (with and without restoration) and reverse transcription PCR for RNA. Results: The acid environment of Bouin's fixative damaged both DNA and RNA. However, amplification was successful when the amplicon length was reduced to about $80 \mathrm{bp}$ for RNA and 100-200 bp for DNA, especially if submitted to DNA reconstruction procedures.

Conclusions: It is possible to recover and analyse DNA and RNA from Bouin's fixed and paraffin wax embedded tissues.

\footnotetext{
A
} rchival tissue is the most widely available material for retrospective clinical studies. With the potential of molecular analysis of nucleic acids, these tissues represent an invaluable resource for the elucidation of disease mechanisms and the validation of gene expression as prognostic or therapeutic target indicators. The most widely used fixative is neutral formalin, but for special purposes other fixatives can be used in histopathology laboratories. Among them, Bouin's solution is often used in French and Canadian laboratories for historical reasons. This fixative solution is composed of a saturated aqueous solution of picric acid, formalin, and acetic acid. ${ }^{1}$ The use of Bouin's solution is labour intensive, requiring multiple alcohol rinses to remove picric acid for optimal preservation and immunohistochemical detection. Tissues are damaged when the picric acid is not removed properly and remains in the tissue throughout the entire processing. In effect, the harmful reaction continues within the embedded specimen for several years. ${ }^{1}$ This fixation method is also used for specific purposes because it better conserves some morphological details, such as nuclear conformation. This property makes Bouin's solution the elective fixative for testis ${ }^{2}$ and lymphoma specimens. $^{3}$

There are conflicting reports about the possible use of these specimens for molecular analyses. Many authors have reported the impossibility of analysing DNA extracted from these tissues with the polymerase chain reaction (PCR). ${ }^{5}$ The main reason is that the enhanced acidic environment causes DNA degradation. Moreover, RNA extraction is difficult in these types of fixed tissues. ${ }^{67}$ We have been able to amplify 200 bp fragments of DNA obtained from Bouin's fixed and paraffin wax embedded tissues only after a specific restoration method to produce longer reconstructed DNA fragments. ${ }^{8}$

\author{
"Bouin's solution is the elective fixative for testis and \\ lymphoma specimens"
}

Whereas most reports have denied the possibility of extracting RNA from routinely paraffin wax embedded, Bouin's fixed specimens, ${ }^{69}$ we have been able to amplify short sequences of RNA/cDNA about $80 \mathrm{bp}$ long.

\section{MATERIALS AND METHODS}

Twenty breast cancer samples were obtained from the pathology department of the National Institute for Cancer Study of Milan, Italy, because most of the material in this institution was routinely fixed in Bouin's solution in the past. All cases chosen were infiltrating ductal breast carcinomas with the same tumour grade and stage, so that histologically homogeneous samples were analysed. All biopsies were carried out from 1980 to 1985, and the fixation and paraffin wax embedding procedure was performed routinely in clinical laboratories. The Bouin's solution used during that period was traditionally prepared in the laboratory, rather than using a commercially manufactured one. DNA and RNA were extracted from $6 \mu \mathrm{m}$ thick sections of Bouin's fixed tissues, as reported previously. ${ }^{10-12}$ Ten sections were cut for each sample.

\section{DNA amplification}

Every DNA sample was restored taking into consideration that the DNA degraded fragments contain mostly single strand nicks, as reported previously. ${ }^{8}$ DNA samples were briefly incubated for one hour at $55^{\circ} \mathrm{C}$ in $100 \mu \mathrm{l}$ of restoration solution containing $100 \mathrm{mM}$ Tris/ $\mathrm{HCl}(\mathrm{pH} 8.3)$, 1.5 $\mathrm{mM} \mathrm{MgCl}_{2}$, $2 \%$ Triton X-100, and $200 \mathrm{mM}$ of each dNTP. After this step, $1 \mathrm{U}$ of classic Taq DNA polymerase (Amersham Biosciences, Uppsala, Sweden) was added and DNA polymerisation was performed at $72^{\circ} \mathrm{C}$ for 20 minutes. Treated samples were then stored at $-20^{\circ} \mathrm{C}$ until processed.

Before the PCR was carried out a denaturation step was performed: $10 \mu \mathrm{l}$ of the solution was denatured at $95^{\circ} \mathrm{C}$ for five minutes and then immediately chilled on ice. As previously reported, ${ }^{8}$ the denaturation step is necessary to destroy the secondary structure of reconstructed DNA. For PCR analysis, the sequences of EGFR (epidermal growth factor receptor), pl6, and TTR (transthyretin gene) were amplified with the primers described in table 1.

PCR was performed in a $50 \mu$ final volume using standard conditions. Every reaction included $250 \mathrm{ng}$ of DNA, 15 pmoles of each primer, $50 \mathrm{mM} \mathrm{KCl}, 1.5 \mathrm{mM} \mathrm{MgCl}_{2}$, $10 \mathrm{mM}$ Tris/ $\mathrm{HCl}$ ( $\mathrm{pH} 9$ at room temperature), $200 \mu \mathrm{M}$ of each dNTP, and $\mathrm{l} U$ of Taq DNA polymerase (Amersham Biosciences). The following amplification programme was used for all amplifications: denaturation at $95^{\circ} \mathrm{C}$ for three minutes; five cycles of $95^{\circ} \mathrm{C}$ for one minute, $60^{\circ} \mathrm{C}$ for one minute, and $72^{\circ} \mathrm{C}$ for one minute; then 45 cycles of $95^{\circ} \mathrm{C}$ for

Abbreviations: EGFR, epidermal growth factor receptor; GAPDH, human glyceraldehyde-3-phosphate dehydrogenase; PCR, polymerase chain reaction; RT, reverse transcription; TTR, transthyretin gene 
Table 1 Sequence of primers and PCR conditions for DNA analysis

\begin{tabular}{|c|c|c|c|c|}
\hline Gene & Primer sequence $5^{\prime}-3^{\prime}$ & Length of product & $\mathrm{Ta}$ & Cycles \\
\hline EGFR & $\begin{array}{l}\text { Forward: GAA GCC AAG CCA AAT GGC A } \\
\text { Reverse: GCT CCA ATA AAT TCA CTG CT }\end{array}$ & $90 \mathrm{bp}$ & 60 & 45 \\
\hline pl6 & $\begin{array}{l}\text { Forward: AGC TTC CT TCC GTC ATG C } \\
\text { Reverse: 5-GCA GCA CCA CCA GCG TG }\end{array}$ & $204 \mathrm{bp}$ & 60 & 45 \\
\hline TTR1 & $\begin{array}{l}\text { Forward: CAG CAG GTT TGC AGT CAG AT } \\
\text { Reverse: GGT ACC CTT GCC CTA GTA AT }\end{array}$ & $291 \mathrm{bp}$ & 60 & 45 \\
\hline TTR2 & $\begin{array}{l}\text { Forward: TGG TGG AAA TGG ATC TGT CTG } \\
\text { Reverse: TGG AAG GGA CAA TAA GGG AAT }\end{array}$ & $333 \mathrm{bp}$ & 60 & 45 \\
\hline
\end{tabular}

30 seconds, $60^{\circ} \mathrm{C}$ for 30 seconds, and $72^{\circ} \mathrm{C}$ for 30 seconds. The lengths of the amplicons were $90 \mathrm{bp}$ for EGFR (GeneBank X17054), 204 bp for pl6 (GeneBank NM_000077), 291 bp for TTR1 (GeneBank M11844), and 333 bp for TTR2 (GeneBank M11844).

Aliquots ( $10 \mu \mathrm{l}$ ) of the amplification products were run on $8 \%$ polyacrylamide gels. Gels were stained with ethidium bromide $(5 \mu \mathrm{g} / \mathrm{ml})$ and recorded using a VersaDoc imaging system (Bio-Rad Laboratories, Hercules, California, USA).

\section{RT-PCR for RNA analysis}

DNase I digestion was performed to eliminate genomic DNA from the RNA solution. The RNA ( $2 \mu \mathrm{g})$ was resuspended in $20 \mu \mathrm{l}$ final volume containing $\mathrm{I} \times$ DNase I buffer, $80 \mathrm{U}$ of RNase inhibitor (Ambion, Austin, Texas, USA), and $10 \mathrm{U}$ of I RNase free DNase (Amersham Biosciences). The reaction was left to proceed at $37^{\circ} \mathrm{C}$ for 20 minutes. To purify RNA from DNase I an extraction with phenol $/ \mathrm{H}_{2} \mathrm{O}$ /chloroform was performed. The final concentration of RNA in the solution was made by precipitation with isopropanol using $5 \mu \mathrm{l}$ of glycogen $(1 \mathrm{mg} / \mathrm{ml})$ as precipitation carrier because of its low concentration. ${ }^{10}{ }^{11}$

Reverse transcription was performed, as described previously, ${ }^{13}$ using $500 \mathrm{ng}$ of total RNA, AMV reverse transcriptase (Promega; Madison, Wisconsin, USA), and sequence specific antisense primer. Table 2 shows the primers and PCR conditions used for RNA analysis.

For $\beta$ actin (GeneBank M10277), we analysed five systems characterised by increasing length of the RT-PCR products $(77,100,120,170$, and $200 \mathrm{bp})$ and for EGFR (GeneBank AF124513) two systems were evaluated (65 and $95 \mathrm{bp}$ ). We also analysed two systems (75 and $103 \mathrm{bp}$ ) for the human glyceraldehyde-3-phosphate dehydrogenase gene (GAPDH;
GeneBank NM_002046). Aliquots $(10 \mu \mathrm{l})$ of each PCR product were visualised on $8 \%$ polyacrylamide gels. Gels were stained with ethidium bromide $(5 \mu \mathrm{g} / \mathrm{ml})$ and recorded using a VersaDoc imaging system (Bio-Rad Laboratories).

\section{RESULTS}

Twenty Bouin's fixed, paraffin wax embedded breast cancer tissues were submitted to DNA and RNA extraction. Nucleic acids were extracted from $6 \mu \mathrm{m}$ sections of paraffin wax embedded blocks. Ten sections were cut from every sample. Means of 257 ng of DNA and 51 ng of RNA were obtained for each $6 \mu \mathrm{m}$ section. Every PCR and RT-PCR analysis was repeated twice to confirm the reproducibility of the results.

DNA samples were amplified with and without the restoration step (table 3). EGFR (100 bp) DNA was amplified in all the treated samples and in 18 of the 20 untreated samples (table 3). For PCR fragments of $204 \mathrm{bp}(\mathrm{pl}$ ), the number of positive amplifications decreased only in the untreated samples (table 3; 15 of 20). For even longer amplification stretches of around $300 \mathrm{bp}$ (TTRl, $291 \mathrm{bp}$; TTR2, $333 \mathrm{bp}$ ), no amplification was seen in untreated samples. In treated samples, the number of positive results decreased with the length of amplicons. For TTRI (table 3; fig 1), seven treated samples were positively amplified and for TTR2 only two treated samples were amplified (fig 1).

For RNA analysis (table 4), all amplicons that amplified successfully were no longer than 65-75 bp (EGFR, $65 \mathrm{bp}$; GAPDH, $75 \mathrm{bp} ; \beta$ actin, $77 \mathrm{bp}$ ). For longer fragments, the positivity rate decreased. For EGFR ( $95 \mathrm{bp}$ ), $\beta$ actin ( $100 \mathrm{bp}$ ), and GAPDH ( $103 \mathrm{bp}$ ), 17 of 20,18 of 20 , and 16 of 20 amplicons were amplified, respectively. Increasing the length of the RT-PCR products decreased the number of positive

Table 2 Sequence of primers and PCR conditions for RNA analysis

\begin{tabular}{|c|c|c|c|c|}
\hline Gene & Primer sequence $5^{\prime}-3^{\prime}$ & Length of product & $\mathrm{Ta}$ & Cycles \\
\hline$\beta$ Actin & $\begin{array}{l}\text { Forward: ATC ACT GCC CTG GCA CCC A } \\
\text { Reverse: CCG ATC CAC ACG GAG TAC TIG }\end{array}$ & 77 bp & 60 & 30 \\
\hline$\beta$ Actin & $\begin{array}{l}\text { Forward: } 5 \text { TIG CCG ACA GGA TGC AGA A } \\
\text { Reverse: the same primer used for } \beta \text {-Act } 77 \text { bases }\end{array}$ & $100 \mathrm{bp}$ & 60 & 30 \\
\hline$\beta$ Actin & $\begin{array}{l}\text { Forward: TGG AGA AGA GCT ACG AGC TG } \\
\text { Reverse : GAA GGT AGT TIC GTG CAT CG }\end{array}$ & $120 \mathrm{bp}$ & 58 & 40 \\
\hline$\beta$ Actin & $\begin{array}{l}\text { Forward: CTG GAC TC GAG CAA GAG AT } \\
\text { Reverse: the same primer used for } \beta \text {-Act } 120 \text { bases }\end{array}$ & 170 bp & 58 & 40 \\
\hline$\beta$ Actin & $\begin{array}{l}\text { Forward: GAG AAG CTG TCC TAC GTC G-3' } \\
\text { Reverse: the same primer used for } \beta \text {-Act } 120 \text { bases }\end{array}$ & $200 \mathrm{bp}$ & 59 & 45 \\
\hline EGFR & $\begin{array}{l}\text { Forward: GGC TCT GGA GGA AAA GAA AG } \\
\text { Reverse: TCA AAA GTG CCC AAC TGC TG }\end{array}$ & $65 \mathrm{bp}$ & 55 & 40 \\
\hline EGFR & $\begin{array}{l}\text { Forward: AAC ATC CTC TGG AGG CTG A } \\
\text { Reverse: TCA AAA GTG CCC AAC TGC TG }\end{array}$ & $95 \mathrm{bp}$ & 55 & 40 \\
\hline GAPDH & $\begin{array}{l}\text { Forward: CCC TCA ACG ACC ACT TTG TCA A } \\
\text { Reverse: GGT CCA CCA CCC TGT TGC T }\end{array}$ & $75 \mathrm{bp}$ & 58 & 30 \\
\hline GAPDH & $\begin{array}{l}\text { Forward: TCC ACC TTा GAC GCT GGG } \\
\text { Reverse: GGT CCA CCA CCC TGT TGC T }\end{array}$ & $103 \mathrm{bp}$ & 58 & 30 \\
\hline
\end{tabular}



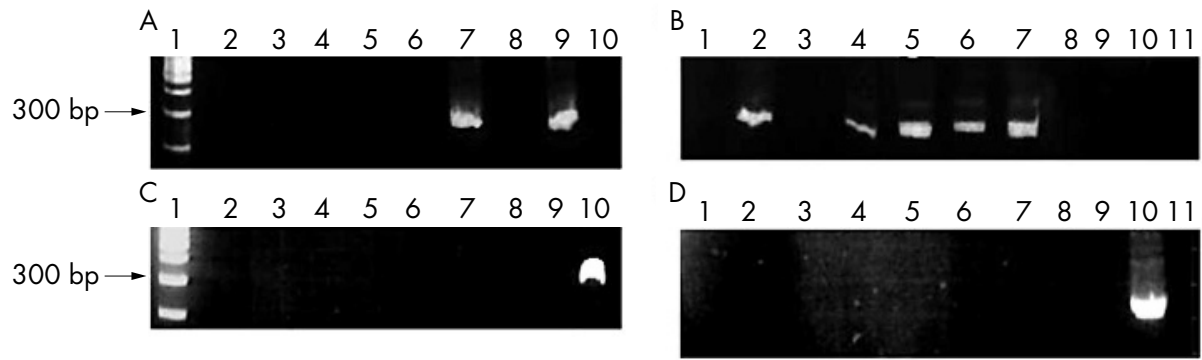

Figure 1 PCR products for TTR1 and TTR2 analysis in Bouin's solution fixed, paraffin wax embedded tissues. (A) TTR1 DNA (291 bp) with the restoration step. Lane 1, molecular size marker; lanes 2-10, DNA from breast cancer cases. (B) TTR1 DNA (291 bp) with the restoration step. Lanes 111, DNA from breast cancer cases. (C) TTR2 gene DNA (333 bp) with the restoration step. Lane 1, molecular size marker; lanes 2-10, DNA from breast cancer cases. (D) TTR gene DNA (333 bp) with the restoration step. Lanes 1-11, DNA from breast cancer cases. PCR, polymerase chain reaction; $T R$, transthyretin gene.

results to seven of 20 samples. No results were obtained for the $\beta$ actin RT-PCR products 170 and 200 bp long.

\section{DISCUSSION}

Nucleic acid degradation depends on environmental factors such as enzymes and temperature, in addition to chemical factors related to fixative solutions. Different fixatives have a different capacity to degrade DNA and RNA. ${ }^{9}$ It has already been shown that DNA from formalin fixed, paraffin wax embedded tissues can be reconstructed to longer fragments, ${ }^{8}{ }^{14}$ but many doubts have been expressed about the possibility of DNA analysis in Bouin's fixed tissues. Bouin's fixative solution has been particularly recommended for testicular and lymphoma biopsies and for historical reasons has also been used in French and Canadian laboratories. Several authors have reported the difficulties related to molecular analysis in Bouin's fixed tissues. ${ }^{6}{ }^{15}$ Here, we show that DNA from Bouin's fixed tissues can be reconstructed and analysed, but to a shorter length than formalin fixed tissues.

"We recommend analysing 100-200 bp fragments of DNA from Bouin's fixed tissues to guarantee amplification, and preferably to use a DNA reconstruction step"

We amplified DNA samples derived from Bouin's fixed tissue sections, with and without a restoration step (table 3). Every PCR and RT-PCR analysis was repeated twice to confirm the reproducibility of the results, which were always consistent. As reported, EGFR DNA (100 bp) was amplified in all treated but in fewer untreated samples. PCR analysis in DNA from Bouin's fixed tissue sections was successful in all samples that had been submitted to reconstruction for fragments up to 100-200 bp. For longer fragments, amplification was successful in only seven of 20 samples using amplicon sizes of $290 \mathrm{bp}$ and only two of 20 samples of $330 \mathrm{bp}$, but only after DNA reconstruction. The inclusion of picric and acetic acid in Bouin's fixative enhances DNA degradation in Bouin's fixed tissues compared with formalin fixed tissues, in which over $300 \mathrm{bp}$ can be amplified. ${ }^{5}$ Therefore, we recommend analysing 100-200 bp fragments of DNA from Bouin's fixed tissues to guarantee amplification, and preferably to use a DNA reconstruction step. ${ }^{8}$

As already reported ${ }^{10}$ it is possible to extract and analyse RNA from formalin fixed, paraffin wax embedded tissues. In routinely treated formalin fixed material, fragments of RNA between 100 and $200 \mathrm{bp}$ can be amplified. RNA obtained from Bouin's fixed, paraffin wax embedded tissues showed a higher degree of degradation and only amplicons less than $100 \mathrm{bp}$ could be successfully amplified (table 4). For fragments around $100 \mathrm{bp}$ long, RNA amplification was successful in a smaller number of cases ( $\beta$ actin, 18 of 20 cases; EGFR, 17 of 20 cases; GAPDH, 16 of 20 cases). For longer RT-PCR fragments of about 120 bp only seven of 20 samples were positive. All cases were negative when fragments of 170-200 bp were analysed, showing the limited length of amplicons that can be used in RT-PCR analysis of Bouin's fixed tissues.
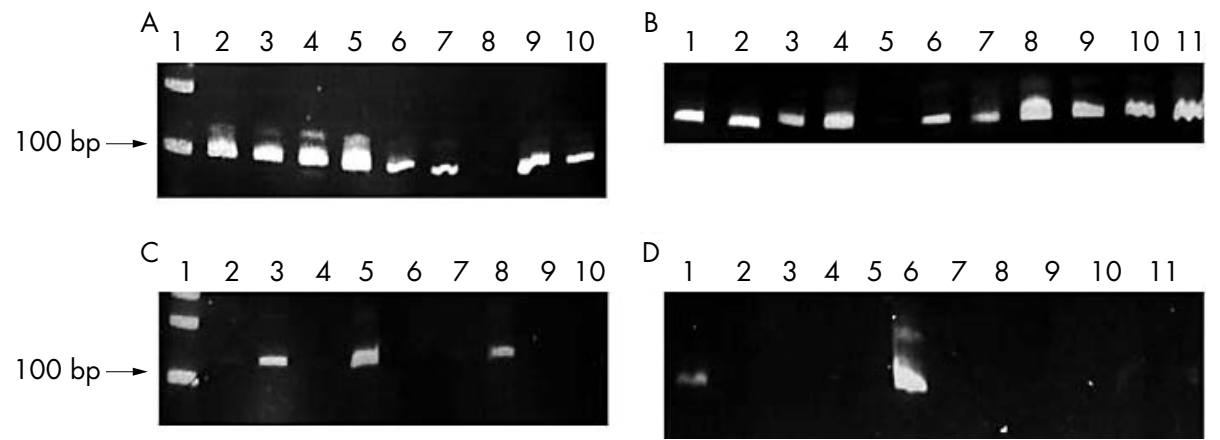

Figure 2 RT-PCR products in Bouin's solution fixed, paraffin wax embedded tissues. (A) mRNA analysis for the $\beta$ actin gene (100 bp). Lane 1, molecular size marker; lanes 2-10, RNA obtained from breast cancer cases. (B) mRNA analysis for $\beta$ actin gene (100 bp). Lanes 1-11, RNA obtained from breast cancer cases. (C) mRNA analysis for $\beta$ actin gene (120 bp). Lane 1, molecular size marker; lanes 2-10, RNA obtained breast cancer cases. (D) mRNA analysis for $\beta$ actin gene (120 bp). Lanes 1-11, RNA obtained from breast cancer cases. RT-PCR, reverse transcription polymerase chain reaction. 


\section{Table 3 DNA amplification results}

\begin{tabular}{lll}
\hline Gene (amplicon size) & Untreated DNA* & Treated DNA† \\
\hline EGFR (100 bp) & $18 / 20$ & $20 / 20$ \\
p16 (204 bp) & $15 / 20$ & $20 / 20$ \\
TRR1 (291 bp) & $0 / 20$ & $7 / 20$ \\
TR2 (333 bp) & $0 / 20$ & $2 / 20$ \\
\hline
\end{tabular}

*DNA not subjected to the restoration step; † DNA subjected to the restoration step.

EGFR, epidermal growth factor receptor; $T R$, transthyretin gene.

\section{Take home messages}

- Bouin's fixative damages both DNA and RNA

- Molecular analyses can be carried out in Bouin's fixed tissues if the amplification fragment is reduced to less then 100 bp for RNA and less than 200 bp for DNA

These findings show that Bouin's fixative damages both DNA and RNA; however, it is possible to perform molecular analyses in these types of tissue by reducing the amplification fragment to less then $100 \mathrm{bp}$ for RNA and less than $200 \mathrm{bp}$ for DNA.

\section{ACKNOWLEDGEMENTS}

We thank Ms S Vincent and Dr S Miertusova for the English revision of the manuscript.

\section{Authors' affiliations}

F Petrera, ICGEB-International Centre for Genetic Engineering and Biotechnology, 99 Padriciano, 34012 Trieste, Italy

S Bonin, G Stanta, Department of Clinical, Morphological and Technological Sciences, University of Trieste, Cattinara Hospital, 447 Strada di Fiume, 34149 Trieste, Italy

J Rosai, Department of Pathology, Istituto Nazionale per lo Studio e la Cura dei Tumori, Milano, Italy

The first two authors contributed equally to this study

Correspondence to: Dr G Stanta, International Centre for Genetic Engineering and Biotechnology, 99 Padriciano, 34012 Trieste, Italy; stanta@icgeb.org

Accepted for publication 3 August 2004
Table 4 RNA amplification results

\begin{tabular}{ll}
\hline Gene & RT-PCR results \\
\hline$\beta$ Actin (77 bp) & $20 / 20$ \\
$\beta$ Actin (100 bp) & $18 / 20$ \\
$\beta$ Actin (120 bp) & $7 / 20$ \\
$\beta$ Actin (170 bp) & $0 / 20$ \\
$\beta$ Actin (200 bp) & $0 / 20$ \\
EGFR (65 bp) & $20 / 20$ \\
EGFR (95 bp) & $17 / 20$ \\
GAPDH (75 bp) & $20 / 20$ \\
GAPDH (103 bp) & $16 / 20$ \\
\hline
\end{tabular}

EGFR, epidermal growth factor receptor; GAPDH, glyceraldehyde-3phosphate dehydrogenase; RT-PCR, reverse transcription polymerase chain reaction.

\section{REFERENCES}

1 Luna LG. Manual of histologic staining methods-AFIP, 3rd ed. New York: Mc Graw-Hill, 1968.

2 Wollina U, Schreiber G, Zollmann C, et al. Lectin-binding sites in normal human testis. Andrologia 1989;21:127-30.

3 Konishi N, Ward JM, Reynolds CW, et al. Thymic T-cell lymphoma with the $\mathrm{CD} 8+(\mathrm{OX}-8), \mathrm{CD} 4+(\mathrm{W} 3 / 25)$ phenotype, induced in $\mathrm{F} 344 / \mathrm{NCr}$ rats by nitroso-2-hydroxypropylurea. Thymus 1988;12:225-37.

4 Greer CE, Peterson SL, Kiviat NB, et al. PCR amplification from paraffinembedded tissues. Effects of fixative and fixation time. Am J Clin Pathol 1991;95:117-24.

5 Gall K, Pavelic J, Jadro-Santel D, et al. DNA amplification by polymerase chain reaction from brain tissues embedded in paraffin. Int $J$ Exp Pathol 1993:74:333-7.

6 Tyrrell L, Elias J, Longley J. Detection of specific mRNAs in routinely processed dermatopathology specimens. Am J Dermatopathol 1995; 17:476-83.

7 Biagini P, Monges G, Cantaloube JF, et al. Detection of gastrin mRNA in paraffin-embedded samples of normal antral mucosae using polymerase chain reaction technique. APMIS 1994;102:526-32.

8 Bonin S, Petrera F, Niccolini B, et al. PCR analysis in archival postmortem tissues. Mol Pathol 2003;56:184-6.

9 Ben-Ezra J, Johnson DA, Rossi J, et al. Effect of fixation on the amplification of nucleic acids from paraffin-embedded material by the polymerase chain reaction. J Histochem Cytochem 1991;39:351-4.

10 Stanta G, Schneider C. RNA extracted from paraffin-embedded human tissues is amenable to analysis by PCR amplification. Biotechniques $1991 ; 11: 304,306,308$.

11 Stanta G, Bonin S, Perin R. RNA extraction from formalin-fixed and paraffinembedded tissues. Methods Mol Biol 1998;86:23-6.

12 Trevisan G, Stinco G, Nobile C, et al. Detection of Borrelia burgdorferi in skin biopsies from patients with morphea by polymerase chain reaction. J Eur Acad Dermatol Venereol 1996;6:15-19.

13 Bonin S, Pascolo L, Croce LS, et al. Gene expression of ABC proteins in hepatocellular carcinoma, perineoplastic tissue, and liver diseases. Mol Med 2002;8:318-25.

14 Imyanitov EN, Grigoriev MY, Gorodinskaya VM, et al. Partial restoration of degraded DNA from archival paraffin-embedded tissues. Biotechniques 2001;31:1000, 1002

15 Tbakhi A, Totos G, Pettay JD, et al. The effect of fixation on detection of B-cell clonality by polymerase chain reaction. Mod Pathol 1999;12:272-8. 